\title{
Physicochemical quality assessment of pollutants in river Benue water in Jimeta/Yola metropolitan, Adamawa State, North Eastern Nigeria
}

\author{
Hong, Aliyu Haliru' ${ }^{1}$ Law, Puong Ling ${ }^{2}$, Selaman, Onni Suhaiza ${ }^{2}$ \\ ${ }^{1}$ Department of Agricultural and Environmental Engineering, Faculty of Engineering, Modibbo Adama University of Technology, Yola, \\ Nigeria \\ ${ }^{2}$ Department of Civil Engineering, Faculty of Engineering, Universiti Malaysia Sarawak, Malaysia
}

Email address:

haliruali@yahoo.com (H. A. Haliru)

\section{To cite this article:}

Hong, Aliyu Haliru, Law, Puong Ling, Selaman, Onni Suhaiza. Physicochemical Quality Assessment of Pollutants in River Benue Water in Jimeta/Yola Metropolitan, Adamawa State, Northeastern Nigeria. American Journal of Environmental Protection.

Vol. 3, No. 2, 2014, pp. 90-95. doi: 10.11648/j.ajep.20140302.18

\begin{abstract}
River Benue has been the second largest river in Nigeria that serves as the major source of municipal water supplies for domestic and irrigation for towns and villages residing along its water course. Samples of water at seven locations from the river were collected for a period of seven months (dry season) when water demand is high in Jimeta/Yola metropolitan area in Northeastern Nigeria and were analyzed using standard methods to determine physicochemical properties and heavy metal concentrations in the water. Turbidity, total solids, total dissolved solids, total suspended solids and nitrate are in the range $(106.4-383.2 \mathrm{NTU}),(403.3-1291 \mathrm{mg} / \mathrm{l}),(370.3-983.8 \mathrm{mg} / \mathrm{l}),(223.0-1391.6 \mathrm{mg} / \mathrm{l})$ and $(1.03$ $-55.84 \mathrm{mg} / \mathrm{l})$ respectively. Results of heavy metals concentrations are $\mathrm{Mn}(0.0004-2.04 \mathrm{mg} / \mathrm{l}), \mathrm{Cu}(0.0003-1.53 \mathrm{mg} / \mathrm{l}), \mathrm{Cd}$ $(0.0002-0.59 \mathrm{mg} / \mathrm{l}), \mathrm{Cr}(0.0002-0.36 \mathrm{mg} / \mathrm{l})$ and $\mathrm{Pb}(0.0002-0.12 \mathrm{mg} / \mathrm{l})$ and are in the order $\mathrm{Mn}>\mathrm{Cu}>\mathrm{Cd}>\mathrm{Cr}>\mathrm{Pb} . \mathrm{The}$ results revealed that physicochemical properties and heavy metal concentrations in the river are slightly higher above the maximum permissible limits set out by Nigerian Federal Ministry of Environment (FME) and WHO (2004) Standards. From the present study, it could be concluded that River Benue is moderately polluted with regard to heavy metals in Jimeta/Yola metropolitan area. Moderate level of pollution in River Benue water calls for sensitization of users to safeguard public health treats.
\end{abstract}

Keywords: Physicochemical Quality Assessment, River Benue, Pollutants, Heavy Metals

\section{Introduction}

Many parts of the world are experiencing growing water stress and water scarcity. Projections indicate that the population living in water - stressed and water - scarce countries will grow from about 1.2 billion or $18 \%$ of the world population in 2007 to 4.0 billion or $44 \%$ of the world population by the year 2050 as reported by [1]. The demand for fresh water to satisfy the ever increasing population of people in the world today is eminent because of the wide gap between the demand and supply of fresh water that existed in almost all part of the world.

The rivers and oceans hold about $97 \%$ of the earth's total water resources while the remaining $3 \%$ is considered to be underground water to be exploited economically. One of the major factors that affect the beneficial use of surface waters such as rivers, streams and ponds for industrial, domestic and agricultural purposes are contamination and pollution due to anthropogenic or human activities which finally end up by disposing the liquid waste into rivers and streams without treatment.

According to the World Commission on Water for the $21^{\text {st }}$ Century, more than half of the world's major rivers are so depleted and polluted that they endanger human health and poison surrounding ecosystems [2]. The sources of water pollution vary and involve almost every significant human activity. These include mostly the dumping of domestic wastes, sewage, agricultural and industrial effluent into water bodies [3].

Lack of adequate water for domestic, irrigation and others purposes in rural and urban centers is one of the most challenging problems in Nigeria today. Access to good adequate water quality is very essential to heath and 
any sustainable development. All human usage of water, either for drinking, irrigation, recreation and industrial processes has some quality criteria requirements to make it acceptable. This quality requirement can be addressed in terms of physicochemical properties of such water [3].

Pollution of rivers and streams flowing through agricultural areas where fungicides, pesticides and herbicides might have been applied and industrial areas where there may have been organic and inorganic waste deposits may all present varied and difficult problems due to drainage into different water bodies. Discharged effluent into a river, may affect aquatic life by depleting dissolved oxygen level in water. As dissolved oxygen drops, fish and other aquatic life are threatened or killed in extreme cases. In this case, dissolved oxygen may be about $3 \mathrm{mg} / \mathrm{l}$ or less. As much as $9.2 \mathrm{mg} / \mathrm{l}$ at $25^{\circ} \mathrm{C}$ is needed for support of aquatic life (Ademoroti, 1996b).

Adefemi [5] reported in their assessment of physicochemical quality of Maji dams in Ekiti State Nigeria discovered the status of sampled waters from four major dams assessed for three years period (wet and dry season). They concluded that determined parameters were higher in dry season than wet season. Statistical analysis conducted revealed that most of the physicochemical parameters are significantly different except temperature, conductivity and dissolved solids $(0.475$ at $\mathrm{P}=0.05)$.

Ogabiela [6] analyzed tannery effluent water from Sharada Industrial Estate Kano for physicochemical parameters of the waste water such as TDS, TS, TSS, conductivity, alkalinity, chloride, COD, BOD and $\mathrm{Cr}$ were determined by standard methods and concluded that the concentrations of parameters were higher than the limit set by the Federal Ministry of Environment for discharge of effluents by tannery sector. Tannery effluents from Sharada Industrial Estate polluted the Chalawa River in Kano.

Study of lead concentration in borehole and well water in Zaria reported $\mathrm{Pb}$ concentration level that ranged from 0.000786 to $0.0595 \mathrm{mg} / \mathrm{l}$ with $91 \%$ of the samples above the $0.01 \mathrm{mg} / 1 \mathrm{WHO}$ drinking water guideline level [7].

Heavy metal level analysis conducted in water and sediments of River Gongola in Adamawa State concluded that heavy metals were higher in the sediment than in water samples for both rivers. $\mathrm{Cr}, \mathrm{Cd}$ and $\mathrm{Pb}$ were higher than acceptable limits set out by [9-10] values in water samples [3-8].

River Benue water is one of the river water susceptible to pollution due to heavy human dependency on these river waters for domestic, industrial, agricultural and recreational activities in Adamawa State. As the river runs through the capital city of the State, its water quality is greatly affected by land use and activities of the area. The public generally perceives river Benue as a waste - dumping conduit. Notably there is indiscriminate dumping of waste and agricultural practices taking place in the area. Waste disposal in the areas is through open dump for solid waste, pit latrines, septic tank for human wastes. Liquid waste are admitted through the major drainage networks and emptied into river Benue.

River Benue water is extensively used for domestic, recreational, industrial and irrigation purposes in the area. Edible vegetable are produced in the dry season that span from the months of October to April annually; apart from fishing, the river also serve as route for the transportation of goods and services from the nearby Republic of Cameroun. All these are viable economic activities that support livelihood of common man in the area. Therefore there is a need for continuous monitoring of the pollutants load in this river water so as to safeguard public health treats from using this water. The objective of this study is to determine the physicochemical quality of pollutant in River Benue at Jimeta metropolitan in Adamawa state.

\section{Materials and Methods}

\subsection{Study Area}

Adamawa State is located in the Northeastern part of Nigeria with a population of 3,737,223 people and land mass of $36,917 \mathrm{~km}^{2}$. Yola (Jimeta) the Adamawa State capital is located between Longitudes $12^{\circ} 26^{\prime} \mathrm{E}$ and Latitude $9^{\circ} 16^{\prime} \mathrm{N}$ (http://www.en.wikipedia.org/wiki/jimeta) along the banks of River Benue [11]. The state is in the Sahel region of Nigeria, generally Semi arid with low rainfall, low humidity and high temperature. The area experiences two distinct wet and dry seasons, the wet season starts from April to October while the dry season starts from November to April. Mean daily temperature fluctuates with season from $25^{\circ} \mathrm{C}$ to $45^{\circ} \mathrm{C}$ and mean annual rainfall received is in the range of $(250-1000 \mathrm{~mm})$. The climate is characterized by high evapotranspiration especially during dry season [11]. Yola, the State capital has an estimated population of 600,000 people.

\subsubsection{River Benue}

River Benue is the longest tributary of River Niger; it covers about $1,083 \mathrm{~km}$ in length. The river rises in Northern Cameroun as B'enoue at about $1,340 \mathrm{~m}$ and in its first $240 \mathrm{~km}$, descends to more than $600 \mathrm{~m}$ over many falls and rapids, the rest of its course are uninterrupted. During flood periods its waters are linked via the Mayo - Kebbi tributary with the Logone, which then flows to Lake Chad. The river is navigable all year by boats drawing less than $0.75 \mathrm{~m}$ and by larger boats for more restricted periods [12]. The Cameroun government built a Dam the river near Lagdo town about $250 \mathrm{~km}$ away from Yola (Fig 1).

\subsubsection{Water Sampling}

Representative samples of the river water body were collected and examined for a period of seven months (October 2012 to April 2013). This period mark the dry season when the demand of water for domestic, irrigation and industrial purposes is very high in the area. Seven sampling stations were chosen along the river over a total distance of $15 \mathrm{~km}$. The names and codes of the stations are: Bwaranji site $\left(S_{1}\right)$, Jimeta water works $\left(S_{2}\right)$, Jimeta bridge 
site $\left(S_{3}\right)$, Gindin Goruba site $\left(S_{4}\right)$, Shinko site $\left(S_{5}\right)$, Gwari market site $\left(S_{6}\right)$ and Geriyo junction site $\left(S_{7}\right)$ figure 2. At each station, samples were collected using 1 liter plastic bottles with screw cap, pre cleaned with hydrochloric acid. Water samples were collected by lowering pre cleaned plastic bottles in the bottom of the water body at a depth of approximately $30 \mathrm{~cm}$ and was allowed to full and overflow before withdrawing the bottles

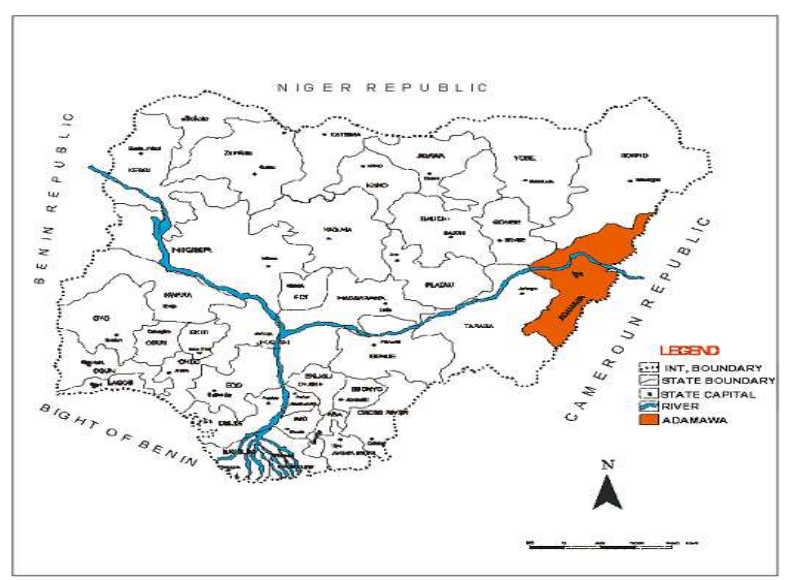

Fig 1. Map of River Benue Traversing the City of Yola.

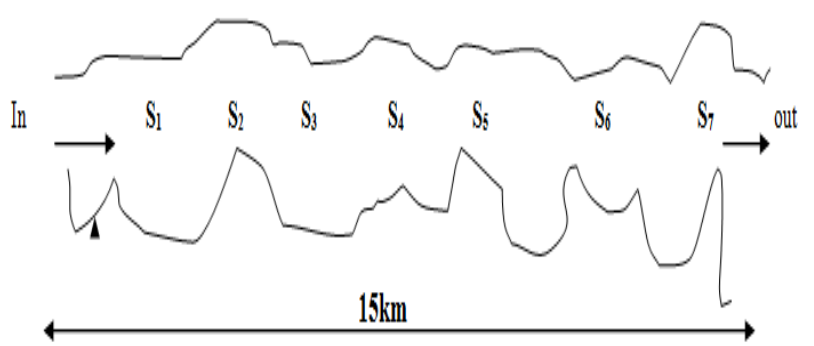

Figure 2. River Benue and location of sampling points of water from $S_{I}$ to $\mathrm{S}_{7}$ and the flow direction.

\subsubsection{Preservation and Storage of Samples}

Due to the fact that changes occur frequently in water, collected samples were transported to the Multipurpose Laboratory of Chemistry Department of Modibbo Adama University of Technology, Yola and analysis was done immediately. In the laboratory on the same day, the sub samples meant for metal analysis that could not commence immediately were stored at $4^{\circ} \mathrm{C}$ or relevant preservative were added depending on the parameter to be determined and duration of preservation as stated by [13].

\subsubsection{Analytical Methods}

The $\mathrm{pH}$ of the water samples collected from different location was measured using a portable digital JENWAY PH meter (Model 3310) equipped with glass electrode. The calibration was done using standard analytical grade buffer solutions of $\mathrm{pH} 4.0,7.0$ and 10 and was used to determine the $\mathrm{PH}$ of the unfiltered water samples in the laboratory. A multipurpose JENWAY portable combined TDS/conductivity meter (4510 model) was used in situ to determine the surface water temperature in the field by inserting the probe portion to a depth of $1 \mathrm{~cm}$ below the water surface for $5 \mathrm{~min}$ until the digital display get stabilized and temperature reading recorded immediately [14]. Total suspended solid (TSS) and total solid (TS) were estimated by gravimetric method as described by [4] $100 \mathrm{ml}$ of the unfiltered portion of the water sample was evaporated in a porcelain dish to dryness which was previously oven dried at temperature of $105^{\circ} \mathrm{C}$, cooled in a desiccator to room temperature to a constant weight. Weight difference between the initial and final that is weight of dish with $100 \mathrm{ml}$ of water and weight of dish after evaporation less weight of dish alone was considered as the weight of (TS). To determine (TSS), $100 \mathrm{ml}$ of water was filtered through $0.45 \mu \mathrm{m}$ cellulose Whatmans filter membrane which was previously oven dried at $105^{\circ} \mathrm{C}$ and weighed to constant weight and the filter paper plus retained solids dried in a desiccator to fixed weight. Digital Turbidometer (Digital $M$ tronics with range of $(0-$ 1000 NTU) were used to measure turbidity of water samples. Dissolved oxygen content of the sampled water was determined using digital dissolved oxygen meter. Nitrate content were determined using well calibrated V2000 multi - analyte photometer while trace and heavy metal of the water samples were carried out with a Varian Mode AA240FS (Fast Sequential Atomic Absorption Spectrometer). Standard methods and procedures outlined by [14] were adopted.

\subsubsection{Data Analysis}

The generated data was processed using Microsoft Excel 2007 software package. Analysis of Variance and student $t$ - test at $95 \%$ confidence level were calculated and results were presented as mean and standard deviation (Mean \pm SD

\section{Results and Discussion}

The mean physicochemical properties of River Benue as observed from various stations are presented in Table 1. The mean temperature $\left(21.4 \pm 1.1^{\circ} \mathrm{C}\right), \quad \mathrm{PH} \quad(7.6 \pm 0.8)$, turbidity $(185.5 \pm 13.6 \mathrm{NTU})$, TS $(914 \pm 45.1 \mathrm{mg} / \mathrm{l})$, TDS $(712.5 \pm 41.0 \mathrm{mg} / \mathrm{l})$, TSS $(949.1 \pm 26.0 \mathrm{mg} / \mathrm{l})$ and electrical conductivity $(692.0 \pm 17.0 \mu \mathrm{s} / \mathrm{cm})$ are however higher than physicochemical parameter data earlier reported for some rivers in Nigeria that are regarded as polluted or contaminated [15]. Study of the physicochemical quality parameters of water samples from Nworie River in Southeastern Nigeria as reported by [16] are in agreement with those of in the current study. However, the higher values of turbidity, total suspended solids, and total solids in this study could be attributed to inputs from surface flooding of excess water from Lagdo dam, runoffs from agricultural lands due to irrigation, earth moving/loosening activities very close to the banks of the river.

The mean value of dissolved oxygen recorded is $5.2 \mathrm{mg} / \mathrm{l}$ with range of $11.7-19.06 \mathrm{mg} / \mathrm{l}$. This value indicated that the river water had an appreciable level of dissolved oxygen capable of supporting aquatic life. As the dissolved 
oxygen of water drops, fish and other aquatic organism life are threatened or killed in extreme cases, minimum dissolved oxygen of $9.2 \mathrm{mg} / \mathrm{l}$ at $25^{\circ} \mathrm{C}$ is needed to support aquatic life [4].

The concentration of nitrate in this study ranged between $1.03-55.84 \mathrm{mg} / \mathrm{l}$ with the mean value of $34.4 \mathrm{mg} / \mathrm{l}$. The values of nitrate concentrations of 51.0, 51.2, 54.4 and $55.84 \mathrm{mg} / 1$ recorded in sampling station $\mathrm{S}_{3}, \mathrm{~S}_{4}, \mathrm{~S}_{6}$ and $\mathrm{S}_{7}$ exceeded the maximum permissible value of $50 \mathrm{mg} / 1$ for drinking water set out by [17]. The implication of this is that high nitrate concentration in water has detrimental effect on infant less than six month old. Nitrate reduces nitrite which oxidizes hemoglobin to methaemoglobin, thereby inhibiting the transport and availability of oxygen around the body or simply causes Cyanosis and asphyxia (blue - baby syndrome) [18-19-25]. The sources of nitrate concentration in water might be from anthropogenic or from the use of fertilizer on agricultural farms.

Table 1. Physicochemical properties of River Benue water at seven sampling stations.

\begin{tabular}{|c|c|c|c|c|c|c|c|}
\hline Parameters & $\begin{array}{c}\text { Sample stations } \\
\mathrm{S}_{1} \\
\end{array}$ & $\mathbf{S}_{2}$ & $\mathbf{S}_{3}$ & $\mathbf{S}_{\mathbf{4}}$ & $\mathbf{S}_{5}$ & $S_{6}$ & $\mathbf{S}_{7}$ \\
\hline Temperature $\left({ }^{\circ} \mathrm{C}\right)$ & $23.0 \pm 0.6$ & $18.0 \pm 0.3$ & $17.9 \pm 1.5$ & $21.0 \pm 1.4$ & $21.8 \pm 2.1$ & $20.3 \pm 0.9$ & $28.0 \pm 0.9$ \\
\hline $\mathrm{pH}$ & $7.4 \pm 1.6$ & $7.43 \pm 1.1$ & $6.9 \pm 1.0$ & $7.9 \pm 0.7$ & $7.2 \pm 2.1$ & $8.3 \pm 0.8$ & $8.2 \pm 0.9$ \\
\hline Turbidity (NTU) & $236.8 \pm 7.8$ & $232.1 \pm 16.2$ & $106.4 \pm 2.0$ & $114.3 \pm 3.9$ & $383.2 \pm 56.4$ & $121.0 \pm 0.9$ & $119.0 \pm 6.3$ \\
\hline $\mathrm{TS} \quad(\mathrm{mg} / \mathrm{l})$ & $403.3 \pm 77.8$ & $615.0 \pm 63.0$ & $1291.1 \pm 31.8$ & $1191.2 \pm 24.0$ & $1061.0 \pm 70.0$ & $900.2 \pm 14.1$ & $936.0 \pm 35.3$ \\
\hline TDS & $983.8 \pm 10.6$ & $379.6 \pm 90.5$ & $370.3 \pm 70.1$ & $789.0 \pm 16.9$ & $836.0 \pm 45.9$ & $809.0 \pm 21.2$ & $820.0 \pm 28.3$ \\
\hline TSS & $1391.6 \pm 28.3$ & $222.9 \pm 31.8$ & $942.0 \pm 1.8$ & $1190.7 \pm 14.1$ & $1061.0 \pm 70.0$ & $900.2 \pm 0.4$ & $936.0 \pm 35.3$ \\
\hline Conductivity & $204.4 \pm 8.4$ & $363.2 \pm 3.4$ & $371.1 \pm 5.4$ & $1045.0 \pm 8.5$ & $239.0 \pm 7.4$ & $1295.0 \pm 15.6$ & $1326.0 \pm 67.2$ \\
\hline Dissolved oxygen & $14.7 \pm 0.4$ & $19.06 \pm 8.5$ & 14.31 .6 & $18.2 \pm 1.3$ & $14.9 \pm 3.5$ & $11.7 \pm 0.9$ & $13.6 \pm 1.3$ \\
\hline Nitrate (mg/kg) & $10.7 \pm 0.4$ & $1.03 \pm 0.8$ & $51.0 \pm 0.8$ & $51.2 \pm 1.1$ & $16.8 \pm 0.9$ & $54.4 \pm 0.9$ & $55.84 \pm 1.2$ \\
\hline
\end{tabular}

$\mathrm{S}_{1}$ Gindin goruba station, $\mathrm{S}_{2}$ Shinko station, $\mathrm{S}_{3}$ Jimeta bridge station, $\mathrm{S}_{4}$ Bwaranji station, $\mathrm{S}_{5}$ Jimeta water works station, $\mathrm{S}_{6}$ Gwari market station, $\mathrm{S}_{7}$ Geriyo junction station.

Table 2. Mean concentrations of heavy metals at different sampling stations along River Benue in Yola Metropolitan.

\begin{tabular}{|c|c|c|c|c|c|c|c|}
\hline Heavy & San & station code/ & centration $(\mathrm{mg} / \mathrm{l})$ & & & & \\
\hline Metals & $\mathrm{S}_{1}$ & $\mathrm{~S}_{2}$ & $\mathrm{~S}_{3}$ & $\mathrm{~S}_{4}$ & $\mathrm{~S}_{5}$ & $\mathrm{~S}_{6}$ & $\mathrm{~S}_{7}$ \\
\hline $\mathrm{Fe}$ & $0.48 \pm 0.5$ & $1.058 \pm 0.1$ & $0.065 \pm 0.07$ & $0.005 \pm 0.002$ & $0.12 \pm 0.1$ & $0.0021 \pm 0.0007$ & $0.326 \pm 0.1$ \\
\hline $\mathrm{Zn}$ & $0.93 \pm 0.02$ & $1.66 \pm 0.4$ & $0.067 \pm 0.02$ & $0.003 \pm 0.002$ & $0.0002 \pm 0.001$ & $0.0098 \pm 0.0002$ & $0.119 \pm 0.06$ \\
\hline $\mathrm{Mn}$ & $1.75 \pm 0.07$ & $2.04 \pm 0.6$ & $0.023 \pm 0.004$ & $0.003 \pm 0.001$ & $0.0004 \pm 0.0002$ & ND & $0.089 \pm 0.05$ \\
\hline $\mathrm{Cu}$ & $1.53 \pm 0.04$ & $0.31 \pm 0.09$ & $0.005 \pm 0.002$ & $0.0007 \pm 0.0001$ & $0.0008 \pm 0.0001$ & $0.0003 \pm 0.0001$ & $0.056 \pm 0.023$ \\
\hline $\mathrm{Cd}$ & $0.12 \pm 0.03$ & $0.59 \pm 0.10$ & $0.004 \pm 0.00$ & $0.0002 \pm 0.00$ & $0.0005 \pm 0.0001$ & $0.0004 \pm 0.0002$ & ND \\
\hline $\mathrm{Cr}$ & $0.36 \pm 0.07$ & $0.038 \pm 0.03$ & $0.027 \pm 0.02$ & $0.0002 \pm 0.00$ & $0.0006 \pm 0.0001$ & $0.0024 \pm 0.00$ & $0.026 \pm 0.001$ \\
\hline $\mathrm{Pb}$ & $0.004 \pm 0.001$ & $0.12 \pm 0.06$ & $0.0007 \pm 0.0001$ & $0.0002 \pm 0.00$ & $0.0023 \pm 0.000$ & $0.002 \pm 0.0001$ & $0.0002 \pm 0.00$ \\
\hline
\end{tabular}

ND: Not detected

Table 3. Heavy metal concentrations in $(\mathrm{mg} / \mathrm{l})$ in some Rivers in Nigeria as compared with WHO (2004) Standards.

\begin{tabular}{|c|c|c|c|c|c|c|c|}
\hline & $\mathbf{F e}$ & Zn & Mn & $\mathrm{Cu}$ & Cd & $\mathrm{Cr}$ & $\mathbf{P b}$ \\
\hline \multicolumn{8}{|l|}{ River } \\
\hline $\begin{array}{l}\text { Benue } \\
\text { (this } \\
\text { work) }\end{array}$ & 0.293 & 0.398 & 0.651 & 0.272 & 0.114 & 0.06 & 0.02 \\
\hline $\begin{array}{l}\text { River } \\
\text { Niger }\end{array}$ & 0.408 & - & 0.035 & - & 0.112 & - & - \\
\hline $\begin{array}{l}\text { Warri } \\
\text { River }\end{array}$ & 1.90 & - & 1.10 & - & 0.229 & 0.539 & 1.08 \\
\hline Ogunpa & & & & & & & \\
\hline $\begin{array}{l}\text { River, } \\
\text { Ibadan }\end{array}$ & 2.20 & - & 1.22 & - & 0.001 & - & 0.205 \\
\hline Rimi & & & & & & & \\
\hline $\begin{array}{l}\text { River, } \\
\text { Kaduna }\end{array}$ & 3.80 & - & - & - & 0.040 & - & 1.30 \\
\hline $\begin{array}{l}\text { FME } \\
\text { limits }\end{array}$ & 0.3 & 5.0 & 2.0 & 1.0 & 0.003 & 0.05 & 0.01 \\
\hline $\begin{array}{l}\text { WHO } \\
\text { (2004) } \\
\text { limits }\end{array}$ & 3.0 & 3.0 & 0.4 & 2.0 & 0.003 & 0.05 & 0.01 \\
\hline
\end{tabular}

Values for other rivers taken from Eneji et al, (2012) Federal Ministry of Environment, Nigeria (FME).
Table 2 presents the mean concentration of heavy metals recorded at each of the seven sampling stations. The ranges of Fe recorded are $(0.0021-1.058 \mathrm{mg} / \mathrm{l})$ with station S6 the lowest and S2 the highest. The mean Fe concentration obtained from this study was $0.293 \mathrm{mg} / \mathrm{l}$ which falls within the range of literature values of $3.80,1.90,0.80$, and $0.408 \mathrm{mg} / \mathrm{l}$ as reported for River Rimi, Ogunpa River, River Warri and River Niger [21-15]. Sources of Fe that are obvious in river water might be from weathering processes of soil formation, municipal drain water, leachate from refuse dump sites which are discharged into river water bodies.

$\mathrm{Zn}$ is one of the most common elements in the earth crust that are found in various component of air, soil, food and water in the environment which plays active role in the enzymatic reaction. The range of $\mathrm{Zn}$ in this study are $0.0002-1.66 \mathrm{mg} / \mathrm{l}$ with station $\mathrm{S}_{2}$ recording the maximum value while $S_{5}$ the least. The mean $\mathrm{Zn}$ concentration of $(0.398 \mathrm{mg} / \mathrm{l})$ was relatively low compared with the standard limits of $5.0 \mathrm{mg} / \mathrm{l}$ (FME) and 3.0mg/l (WHO) for drinking water. Emeshili and Egboh (2007) and Eneji et al; (2012) reported low value of $\mathrm{Zn}$ concentration $(0.02 \pm 0.007 \mathrm{mg} / \mathrm{l})$ for Ethiope River in Delta State, while high value of 
$10.3 \mathrm{mg} / \mathrm{l}$ was reported for River Calabar [23].

$\mathrm{Mn}$ is one of the essential nutrient elements required for the growth and well being of plants and animals. Water body containing excessive level of Mn may impair objectionable staining properties on cloth washing operations. Mean concentration of $\mathrm{Mn}(0.651 \mathrm{mg} / \mathrm{l})$ was higher than reported value of Niger River $(0.035 \mathrm{mg} / \mathrm{l})$ and much lower than River Rimi in Kaduna State $(1.30 \mathrm{mg} / \mathrm{l})$. The value recorded in this work is below the maximum permissible limit set out by [17].

Copper has been classified as one of the essential element required by man to promotes activity of enzyme systems in human body however, it becomes toxic to man when ingested in excess of tolerable limit [24]. The mean concentration of copper in this study is $0.272 \mathrm{mg} / \mathrm{l}$ which is below the WHO maximum limit of acceptability level of $2.0 \mathrm{mg} / \mathrm{l}$ in drinking water. However, the value of $1.53 \pm 0.04 \mathrm{mg} / 1$ at $S_{1}$ which is above the Nigeria Federal Ministry of Environment $\mathrm{g} / \mathrm{l}$ limit of $1.0 \mathrm{mg} / \mathrm{l}$ is a serious cause for concern as this area is known for irrigation of edible vegetables. Continuous use of this copper elevated level water to grow crops might infiltrate into the ground and contaminate ground water especially in shallow ground water level or vegetables might take up to a phytotoxic level and gain entrance into the food chain, thereby putting consumers to risk of gastrointestinal disorder. Municipal effluents and leachates from solid waste dumps could contribute to the copper levels in the river water.

The major route through which $\mathrm{Cd}$ enters the aquatic ecosystems in Jimeta/Yola metropolitan area is through the discharge of wastewaters from electroplating, chemical industries, harzadous wastes, fireworks and cadmium batteries. The mean value of Cd obtained is $0.114 \mathrm{mg} / \mathrm{l}$, the values are in agreement with the reported values in River Niger, but higher than Ogunpa River in Ibadan, Rimi River in Kaduna. The value is also above the Federal Ministry of Environment (FME) and WHO standards of $0.003 \mathrm{mg} / \mathrm{l}$ bench mark for drinking water (Table 3). Using this water for drinking without adequate treatment may be toxic to kidney and other body organs.

$\mathrm{Cr}$ plays a key role in the metabolism of sugar in plants and animals, it also regulate the role insulin molecule plays in transporting glucose into the cells for glycolysis. As shown in Table 3, the mean concentration of $\mathrm{Cr}$ is $0.06 \mathrm{mg} / \mathrm{l}$, is in the range of $0.0002-0.36 \mathrm{mg} / \mathrm{l}$. This value is slightly higher than the permissible limit of $0.05 \mathrm{mg} / \mathrm{l}$ set out by FME and WHO (2004) and much lower than River Warri in Table 3. Cr sources in river Benue could be attributed to surface runoffs, discarded chromium batteries and leachates from solid waste dumps.

$\mathrm{Pb}$ is well known as cumulative poison that has several deleterious effects on public health even at trace concentration in the body. It causes cancer, interfere with vitamin D metabolism, and affect mental development in infants, toxic to the central and peripheral nervous systems. In this study, a range of $0.0002-0.12 \mathrm{mg} / \mathrm{l}$ with mean of $0.02 \mathrm{mg} / \mathrm{l}$ of $\mathrm{Pb}$ was observed. This value is higher than
$0.01 \mathrm{mg} / 1$ set by FME and WHO (2004) bench mark for drinking water. This result is higher than result of $\mathrm{Pb}$ concentration of $0.004-0.015 \mathrm{mg} / \mathrm{l}$ reported in [25] for Lake Kainji in Central Nigeria.

\section{Conclusion}

The mean concentrations of physicochemical quality parameters of River Benue at Yola in Adamawa State monitored for seven month in dry season period (October 2012 - April 2013) indicated elevated levels of turbidity, total solids, and total suspended solids due to flooding and anthropogenic activities. Nitrate concentrations at some locations along the river are also elevated above maximum permissible limit set out by WHO Standards. The presence of high levels of concentration of $\mathrm{Cd}, \mathrm{Cu}, \mathrm{Cr}$ and $\mathrm{Pb}$ at Gindin Goruba and Shinko sampling stations are a source of serious concern to public health using the river water. In general, heavy metals concentrations in the river water are in the following trend, $\mathrm{Mn}>\mathrm{Zn}>\mathrm{Cu}>\mathrm{Fe}>\mathrm{Cd}>\mathrm{Cr}>\mathrm{Pb}$. Public sensitization of the water users is required in order to protect and safeguard public health.

\section{References}

[1] Comprehensive Assessment of Water Management in Agriculture.(2007). Water for Food for Life: A Comprehensive Assessment of Water Management in Agriculture. London: Earthscan and Colombo: International Water Management Institute.

[2] Inter - press Service (IPS) (1999). Most Rivers in the World are polluted Washington D.C Inter - press Service Wire Service, pp. $38-41$

[3] Maitera, O.N, Ogugbuaja, V.O , Barminas, J.T (2010). An assessment of the organic Pollution levels of River Benue in Adamawa.State, Nigeria Journal of Environmental Chemistry and Ecotoxicology Vol. 2(7), pp. 110 - 116

[4] Ademoroti, C.M.A (1996b). Environmental Chemistry and Toxicology. Fodulex press Ltd. Ibadan. pp. $79-121$.

[5] Adefemi SS, Asaulo SS, Olaofe O (2007). Assessment of physicochemical status of water of Maji - dams in Ekiti State Nigeria Pakistan J. Nutrition 6(6):657 - 659.

[6] Ogabiela, E.E, Agunwa, U.B, Lawal, F.A, Awoeye, L.D, (2007), Analysis of tannery effluent from the confluence of discharge point at sharada industrial estate in Kano, Nigeria J. Chem. Soc. Nigeria, 32 (2):17 - 19

[7] Musa, H. Yakasai, I .A and Musa, A.H. (2004), Determination of lead concentration in well And Borehole Water in Nigeria, Chemclass Journal. $14-18$

[8] Maitera, O.N, Barminas, J.T, Magili, S.T (2011). Determination of Heavy Metal Levels in

[9] Water and Sediments of River Gongola in Adamawa State, Nigeria, Journal of Emerg. Trends in Engineering and Applied Science (JETEAS) 2(5): $891-896$.

[10] WHO (2006). Guideline for Drinking Water Quality, First Addendum to the Third Edition Volume 1 Recommendations, pp. $491-493$. 
[11] NAFDAC (2001), National Agency for Food and Drug Administration and Control in Nigeria, Drinking Water Regulations, In NAFDAC Consumer Bulletin Oct - Dec, No 19.

[12] Adebayo, A.A, Tukur, A. L (1999). Adamawa State in Maps. Paraclete publishers, Yola.

[13] Encyclopedia Britannica (2014), River Benue, Retrieved from http://www.britannica.com/EBchecked/topic/61238/ Benue.

[14] APHA (1985). Standard Methods for the Examination of Water and Waste Water. (15 ${ }^{\text {th }}$ Edition) Washington D.C America Public Health Association, pp. 1134 APHA (1992). Standard Methods for the Examination of Water and Waste Water. $\left(18^{\text {th }}\right.$ Edition $)$ American Public Health Association.

[15] Eneji, I.S, Sha,Ato, R and Annune, P.A (2012). An assessment of metal loading in River Benue in the Makurdi Metropolitan Area in Central Nigeria. Journal of Environ Monit. Assess (2012) 184:201 - 207.

[16] Manila, P. N. \& Njoku, J.O. (2009) The Chemical analysis of the water and sediment of Nworie River in Owerri, Imo State. Journal of Chemical Society of Nigeria, 34(2), $94-$ 100.

[17] WHO, (2004). Guideline for Drinking Water Quality. $3^{\text {rd }}$ Edition Vol.1Recommendation, Geneva, 515.

[18] WHO, (1985). Health hazards from nitrate in Drinking water. WHO Regional Office for Europe.
[19] Abdullahi, A.S, Funtua, I.I, Alagbe, S.A, Zabroski, P, and Dewu, B.B.M (2010) Investigation of Groundwater quality for Domestic and Irrigation Purposes around Gubrunde and Environs, Northeastern Nigeria Journal of American Science, $6(12)$

[20] Longe E.O and Balogun M.R, (2010)Groundwater Quality Assessment near a Municipal Landfill, Lagos, Nigeria, Res. Journal of Applied Science in Eng. Techno, 2(1): 39 - 44

[21] Oboh, I. P, \& Edema, C.U. (2007), Levels of Heavy metals in water and fishes from River Niger, Journal of Chemical Society of Nigeria, 32(2), $29-34$.

[22] Egboh, S.H.O, \& Emeshili, E.M. (2007) Physicochemical characteristics of River Ethiope Source in Umuaja, Delta State Journal of Chemical Society of Nigeria, 32(2), $72-76$

[23] Kakulu, S.E., and Osibanjo, O. (1988). Trace Heavy metal pollution studies in sediments of The Niger Delta area of Nigeria, Journal of Chemical Society of Nigeria, 13, 22 - 26

[24] NIS, (2007), Nigerian Industrial Standards, Standard Organization of Nigeria NIS554, pp: 30.

[25] Amoo, A.I, Adebayo, O.T, and Lateef, A.F. (2005). Evaluation of heavy metals in fishes, Water and sediments of Lake Kainji, Nigeria Journal of Food, Agriculture \& Environment, 3(1), 209- 212 